\title{
Front Matter: Volume 8707
}

, "Front Matter: Volume 8707," Proc. SPIE 8707, Technologies for Synthetic Environments: Hardware-in-the-Loop XVIII, 870701 (4 June 2013); doi: $10.1117 / 12.2031919$

SPIE Event: SPIE Defense, Security, and Sensing, 2013, Baltimore, Maryland, SPIE. United States 


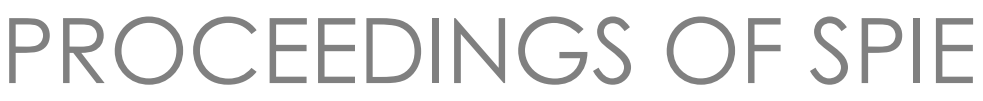

\section{Technologies for Synthetic Environments: Hardware-in-the- Loop XVIII}

James A. Buford Jr.

R. Lee Murrer Jr.

Gary H. Ballard

Editors

2 May 2013

Baltimore, Maryland, United States

Sponsored and Published by

SPIE 
The papers included in this volume were part of the technical conference cited on the cover and title page. Papers were selected and subject to review by the editors and conference program committee. Some conference presentations may not be available for publication. The papers published in these proceedings reflect the work and thoughts of the authors and are published herein as submitted. The publisher is not responsible for the validity of the information or for any outcomes resulting from reliance thereon.

Please use the following format to cite material from this book:

Author(s), "Title of Paper," in Technologies for Synthetic Environments: Hardware-in-the-Loop XVIII, edited by James A. Buford Jr., R. Lee Murrer Jr., Gary H. Ballard, Proceedings of SPIE Vol. 8707 (SPIE, Bellingham, WA, 2013) Article CID Number.

ISSN: 0277-786X

ISBN: 9780819494986

Published by

SPIE

P.O. Box 10, Bellingham, Washington 98227-0010 USA

Telephone +1 3606763290 (Pacific Time) · Fax +1 3606471445

SPIE.org

Copyright (C) 2013, Society of Photo-Optical Instrumentation Engineers.

Copying of material in this book for internal or personal use, or for the internal or personal use of specific clients, beyond the fair use provisions granted by the U.S. Copyright Law is authorized by SPIE subject to payment of copying fees. The Transactional Reporting Service base fee for this volume is $\$ 18.00$ per article (or portion thereof), which should be paid directly to the Copyright Clearance Center (CCC), 222 Rosewood Drive, Danvers, MA 01923. Payment may also be made electronically through CCC Online at copyright.com. Other copying for republication, resale, advertising or promotion, or any form of systematic or multiple reproduction of any material in this book is prohibited except with permission in writing from the publisher. The CCC fee code is 0277-786X/13/\$18.00.

Printed in the United States of America.

Publication of record for individual papers is online in the SPIE Digital Library.

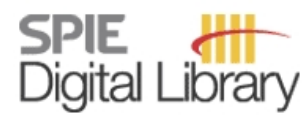

SPIEDigitallibrary.org

Paper Numbering: Proceedings of SPIE follow an e-First publication model, with papers published first online and then in print and on CD-ROM. Papers are published as they are submitted and meet publication criteria. A unique, consistent, permanent citation identifier (CID) number is assigned to each article at the time of the first publication. Utilization of CIDs allows articles to be fully citable as soon as they are published online, and connects the same identifier to all online, print, and electronic versions of the publication. SPIE uses a six-digit CID article numbering system in which:

- The first four digits correspond to the SPIE volume number

- The last two digits indicate publication order within the volume using a Base 36 numbering system employing both numerals and letters. These two-number sets start with 00, 01, 02, 03, 04, $05,06,07,08,09,0 A, 0 B \ldots 0 Z$, followed by 10-1Z, 20-2Z, etc.

The CID Number appears on each page of the manuscript. The complete citation is used on the first page,

and an abbreviated version on subsequent pages. Numbers in the index correspond to the last two digits of the six-digit CID Number. 


\section{Contents}

$\checkmark \quad$ Conference Committee

\section{SESSION 1 HARDWARE-IN-THE-LOOP I}

870702 Analytic determination of optimal projector lens design requirements for pixilated projectors used to test pixilated imaging sensors [8707-1]

J. P. Rice, National Institute of Standards and Technology (United States)

870703 A two-color 1024x1024 dynamic infrared scene projection system [8707-2]

J. LaVeigne, G. Franks, M. Prewarski, Santa Barbara Infrared Inc. (United States)

\section{SESSION 2 HARDWARE-IN-THE-LOOP II}

870706 Characterization of SWIR hyperspectral imager with a multispectral polarized scene projector [8707-5]

N. Gupta, U.S. Army Research Lab. (United States)

870707 High-dynamic range DMD-based infrared scene projector [8707-6]

D. J. Mansur, R. Vaillancourt, R. Benedict-Gill, S. P. Newbry, J. Rentz Dupuis, OPTRA, Inc. (United States)

870709 Calibration of IR test chambers with the missile defense transfer radiometer [8707-8]

S. G. Kaplan, S. I. Woods, National Institute of Standards and Technology (United States);

A. C. Carter, Booz Allen Hamilton, Inc. (United States); T. M. Jung, Jung Research and Development Corp. (United States)

8707 OA Precision radiometric surface temperature (PRST) sensor [8707-9]

J. T. Daly, C. Roberts, A. Bodkin, Bodkin Design \& Engineering LLC (United States);

R. Sundberg, Spectral Sciences, Inc. (United States); S. Beaven, J. Weinheimer, Space

Computer Corp. (United States)

\section{SESSION 3 HARDWARE-IN-THE-LOOP III}

8707 OB Development of tools, technologies, and methodologies for imaging sensor testing [8707-10]

H. Lowry, K. Bynum, S. Steely, R. Nicholson, H. Horne, Aerospace Testing Alliance (United States)

8707 OC Dynamic thermal signature prediction for real-time scene generation [8707-11]

C. L. Christie, E. Gouthas, Defence Science and Technology Organisation (Australia);

O. M. Williams, Daintree Systems Pty Ltd. (Australia); L. Swierkowski, Defence Science and Technology Organisation (Australia) 
8707 OD Coding for parallel execution of hardware-in-the-loop millimeter-wave scene generation models on multicore SIMD processor architectures [8707-12]

R. F. Olson Jr., U.S. Army Aviation and Missile Command (United States)

8707 OE The design of flight motion simulators: high accuracy versus high dynamics [8707-14]

R. W. Mitchell, Ideal Aerosmith Inc. (United States)

Author Index 


\title{
Conference Committee
}

\author{
Symposium Chair
}

Kenneth R. Israel, Major General (USAF Retired) (United States)

Symposium Cochair

David A. Whelan, Boeing Defense, Space, and Security

(United States)

\section{Conference Chairs}

James A. Buford Jr., U.S. Army Aviation \& Missile Research, Development and Engineering Center (United States)

R. Lee Murrer Jr., Millennium Engineering and Integration Company (United States)

Gary H. Ballard, U.S. Army Aviation and Missile Research, Development and Engineering Center (United States)

\section{Conference Program Committee}

James A. Annos, Naval Air Warfare Center Weapons Division (United States)

Dennis H. Bunfield, The AEgis Technologies Group, Inc. (United States) Raul Fainchtein, Johns Hopkins University Applied Physics Laboratory (United States)

Kevin Fisher, ACUTRONIC Switzerland Ltd. (Switzerland)

Jeffrey P. Gareri, Simulation Technologies, Inc. (United States)

Hajin J. Kim, U.S. Army Research, Development and Engineering Command (United States)

John M. Lannon Jr., RTI International (United States)

Heard S. Lowry, Aerospace Testing Alliance (United States)

William M. Lowry, U.S. Army Redstone Technical Test Center (United States)

Robert W. Mitchell, Ideal Aerosmith, Inc. (United States)

Joseph W. Morris, U.S. Army Aviation and Missile Research, Development and Engineering Center (United States)

Ronald J. Rapp, Air Force Research Laboratory (United States)

Joseph P. Rice, National Institute of Standards and Technology (United States)

Donald R. Snyder, Air Force Research Laboratory (United States)

Florence C. Solomon, U.S. Air Force (United States)

Leszek Swierkowski, Defence Science and Technology Organisation (Australia) 
Mark Umansky, U.S. Army Aviation and Missile Research,

Development and Engineering Command (United States)

Brian K. Woode, Naval Air Warfare Center Aircraft Division (United States)

\section{Session Chairs}

1 Hardware-in-the-Loop I

Joseph Rice, National Institute of Standards and Technology (United States)

James A. Buford Jr., U.S. Army Aviation \& Missile Research, Development and Engineering Center (United States)

R. Lee Murrer Jr., Millennium Engineering and Integration Company (United States)

Gary H. Ballard, U.S. Army Aviation \& Missile Research, Development and Engineering Center (United States)

Heard S. Lowry, Aerospace Testing Alliance (United States)

2 Hardware-in-the-Loop II

Darian Trimble, The AEgis Technologies Group, Inc. (United States)

Dennis H. Bunfield, The AEgis Technologies Group, Inc. (United States)

Raul Fainchtein, Johns Hopkins University Applied Physics Laboratory (United States)

Kevin Fisher, ACUTRONIC Switzerland Ltd. (Switzerland)

3 Hardware-in-the-Loop III

Jeffrey P. Gareri, Simulation Technologies, Inc. (United States)

Robert W. Mitchell, Ideal Aerosmith, Inc. (United States)

Joseph P. Rice, National Institute of Standards and Technology (United States) 